\title{
PERORMANCE EVALUATION OF LIQUID-COOLED PHOTOVOLTAIC SYSTEM USING NUMERICAL METHOD
}

\author{
Yasamin Khanjari', Alibakhsh Kasaeian', Fatolah Pourfayaz' ${ }^{1}$, Reza Alayi ${ }^{2}$ \\ 1 Department of Renewable Energies, Faculty of New Science and Technologies, University of Tehran, Tehran, \\ Iran, e-mail: alikasaeian44@yahoo.com \\ 2 Department of Mechnical Engineering, Germi Branch, Islamic Azad University, Germi, Iran, e-mail: reza.alayi@ \\ yahoo.com
}

Received: 2016.06.18

Accepted: 2016.09.08

Published: 2016.12.01

\begin{abstract}
The purpose of present study is establishing a simulation model to consider the performance of a water photovoltaic thermal system $(\mathrm{PV} / \mathrm{T})$ via the computational fluid dynamics method (CFD). The proposed model includes a water riser tube and an absorber plate to consider the conduction and convection heat transfer mechanisms. The simulation procee was carried out in the ANSYS FLUENT software. The effects of two different parameters on the efficiency and performance of the system were investigated numercically. The performance of the PV/T system versus the changes on the absorbed radiation on the plate and the inlet fluid temperature were analyzed. The temperature distribiution of different sections of the system was obtained. For validation of the presented method, a comparison study was carried out with the experimental results in the literature; satisfactory convergences were found between the measured data and the experimental results.
\end{abstract}

Keywords: photovoltaic thermal; water-cooled; simulation; performance.

\section{INTRODUCTION}

Energy is the most essential necessity of any industry in the world. Due to environmental challenges and limitation of traditional fossil resources, renewable energy has been introduced as a clean and environment-friendly substitute for fossil fuels. Among different types of renewable energies, solar is one the most promising sources. The conversion of solar radiation into electricity is performed in photovoltaic cells. Intense radiation of sunlight on PV module in high ambient temperature results in rising temperature and electrical efficiency drop. With passing a fluid behind the PV panel, the electrical efficiency loss will be prevented. The heated fluid can also be used for various thermal applications. Photovoltaic thermal or $\mathrm{PV} / \mathrm{T}$ devices are new hybrid energy capturing tools that that combine photovoltaic technology and solar thermal collectors to produce both electricity and heat from solar radiation at the same time. $\mathrm{PV} / \mathrm{T}$ can be utilized in places with limited access to grid power. Also this technology can be implemented in power generation industry to provide preheated water in industrial scale. Among the fluids that can be circulated in $\mathrm{PV} / \mathrm{T}$, water is the most common. Water PV/T systems have higher efficiency compared to air PV/T systems [15]. Considering different structures, sheet and tube is easy to manufacture, but has $2 \%$ less efficiency compared to other types of water PV/T [6]. More than $75 \%$ of all installed PV/T systems in the world are water types, especially sheet and tube [1].

Zondag et al. [18] investigated the efficiency of different PV/T systems in a theoretical study. The nine different designs were evaluated. The best thermal performance is gained by the channel-above-PV design, the two-cover sheet-andtube design and the insulated two-absorber. Fur- 
thermore, the types of their PV lower channels reached near the highest efficiency value in nine different designs. Although the sheet and tube design is a better choice due to ease of construction.

Modeling of solar irradiation, convection and radiation heat transfer mechanisms are studied via CFD method by Selmi et al. [12]. It was observed that the temperature is lower in the case of using forced flow water than that of without flow. A similar experimental setup was built to consider validation of simulation model. There was a good agreement between the experimental and simulated results. Siddiqui et al. [17] developed a numerical model to compare hybrid PV/T system and PV module. The electrical and thermal sections were coupled to obtain a multi-physics model. The effect of some parameters such as absorbed radiation, thermal contact resistance, inlet temperature and inlet velocity were also investigated. It was deduced that PV/T systems can be applied in places with high solar irradiance and ambient temperature.

A dynamic simulation was implemented by Bhattarai et al. [3] to compare the performance of sheet and tube PV/T system with solar collector. They developed a one-dimensional model by solving energy conservation equations in different sections of the system simultaneously. The numerical results were in a good agreement with the measured data from experimental setup. It was found that daily thermal efficiency of solar collector was $18 \%$ greater than that of the $\mathrm{PV} / \mathrm{T}$ system. While the primary energy saving of the $\mathrm{PV} / \mathrm{T}$ system was higher than that of the solar collector.

Cerón et al. [4] developed a three-dimensional model for sheet and tube flat plate collector. In their investigation, different heat transfer mechanisms were considered in a steady coupled simulation. The numerical results were validated with experimental data and the common correlations of heat transfer. More over Nusselt number of convection heat transfer for water fluid inside the tubes was derived.

An innovative design of $\mathrm{PV} / \mathrm{T}$ system with roll-bond structure was represented by Aste et al. [2]. Also a simulation model was obtained by solving the related energy balances of the system to evaluate the thermal and electrical performance. An experimental PV/T prototypes had been installed and monitored during 18 months by Haurant et al. [11]. They also represented a simulation model for mentioned PV/T system in
TRNSYS. The results of simulation and monitored data were compared. Good agreement was observed between simulation and experimental results. A prototype of mono-crystalline silicon module had been experimented to consider the effect of using water-cooling on performance by Spertino et al. [13]. Also using a low weight plastic-laminated sandwich instead of glass was tested. The results indicate that working fluid must be used according to the location and the season of the year. Variation of the performance improvement versus flow rates of fluid are studied in daily simulations.

Tse et al. [16] examined advantages of using water PV/T system in office scale building. This system supported electricity and hot water demand by computer program. An economic analysis was also carried out to consider the time value of money. The study reflected the potential of applying PV/T technologies in real office buildings in a certain climatic region like Hong Kong.

As discussed above about the literature, the previous numerical or theoretical studies in the field of $\mathrm{PV} / \mathrm{T}$ systems were mainly based on solving energy balance equations for specific cases. Lack of a general method in which we can perform a parametric analysis is observed in literature. CFD is a suitable tool for predicting different variable distribution and values in all sections of system. Literature review reveals that CFD is applied rarely in field of PV/T. In fact, the numerical works using CFD are often related to other solar systems such as trough collectors or flat plate collectors $[8,9]$. The objective of the present work is to propose a comprehensive numerical simulation by using CFD method to evaluate the performance of a photovoltaic thermal system. The effects of inlet fluid temperature and absorbed solar radiation on performance are investigated in the ANSYS fluent. The results are represented in a form of heat transfer coefficient, outlet temperature, and absorber plate temperature and energy efficiencies (both electrical and thermal).

\section{DESCRIPTION OF THE MODEL GEOMETRY}

The geometry model is drawn in CATIA software and then imported to ANSYS workbench. The analysis is carried out in ANSYS fluent. The represented PV/T model consists of a glass cover, 
a photovoltaic panel and a thermal sheet and tube collector in the configuration of header and riser. Five same riser tubes are used. In order to reduce the calculation cost of simulation, the model can be simplified to just one riser tube $[5,7,14]$. A sketch of initial and final model created in ANSYS are shown in Figure 1. Also Relevant dimensions of different sections gathered in Table 1.

\section{FLUID FLOW CHARACTERISTICS}

The Reynolds number and the Grashof number are examined to find out the flow regime for forced convection and natural convection, respectively. The Richardson number is calculated to consider whether the fluid flow is natural, forced or mixed. Gravitational acceleration as a function of the setup tilt angle must be accounted in the simulation procedure. In constant velocity of $0.06377 \mathrm{~m} / \mathrm{s}$ and tilt angle of $35^{\circ}$, the dimensionless numbers are computed. Dimensionless numbers are tabulated in Table 2. Results show that in the present work, the fluid flow is laminar, mixed and fully developed.

$\mathrm{Re}, \mathrm{Pr}, \mathrm{Gr}, \mathrm{Ra}$ and $\mathrm{Ri}$ are referred to Reynolds, Prandtl, Grashof, Rayleigh and Richardson numbers, respectively. In which, $\mathrm{T}$ is temperature $(\mathrm{K}), \mathrm{V}$ is velocity of the water $(\mathrm{m} / \mathrm{s}), \mu$ is the viscosity of water (Pa.s), $\rho$ is density of water $(\mathrm{kg} /$ $\left.\mathrm{m}^{3}\right)$, D is hydraulic diameter $(\mathrm{m})$, $\mathrm{g}$ is gravitational acceleration $\left(\mathrm{m} / \mathrm{s}^{2}\right)$ and $\beta$ is setup tilt angle $\left(^{\circ}\right)$. The subscripts of out and in represent the outlet and inlet conditions, respectively.

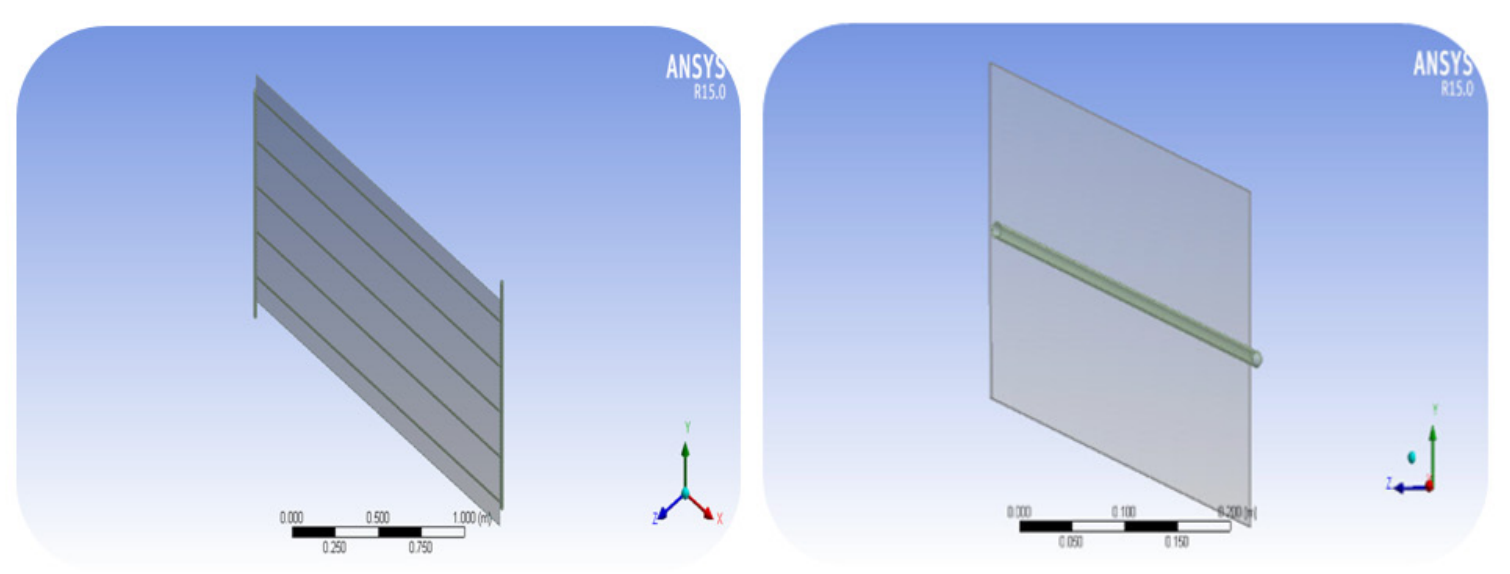

Fig. 1. Sketch of the initial (left) and final model (right)

Table 1. Dimensions and characteristics of different sections of the model

\begin{tabular}{|c|c|c|c|c|}
\hline Risers Tubes & Absorber Plate & \multicolumn{2}{|c|}{ Photovoltaic panel } & Glass \\
\hline Number: 5 & Length:2(m) & Number of cells: 60 & Length: $1.64(\mathrm{~m})$ & Emissivity: 0.88 \\
\hline Thickness: $0.001(\mathrm{~m})$ & Width: $1(\mathrm{~m})$ & $\eta_{\mathrm{r}}=12 \%$ at $0^{\circ} \mathrm{C}$ & Width: $0.99(\mathrm{~m})$ & \\
\hline Outer diameter: $0.01(\mathrm{~m})$ & Thickness: $0.002(\mathrm{~m})$ & $\beta_{r}=0.0045^{\circ} \mathrm{C}^{-1}$ & Absorptance: 0.9 & \\
\hline Length: ${ }^{2}(\mathrm{~m})$ & & & Emissivity: 0.88 & \\
\hline Spacing: $0.2(\mathrm{~m})$ & & & & \\
\hline
\end{tabular}

$\eta_{r}$ and $\beta_{r}$ are the nominal cell efficiency and temperature coefficient $\left({ }^{\circ} \mathrm{C}^{-1}\right)$, respectively. These parameters are supplied by the PV module manufacturer.

Table 2. Dimensionless numbers in constant velocity

\begin{tabular}{|c|c|c|c|c|c|c|}
\hline $\mathrm{T}(\mathrm{K})$ & $\operatorname{Pr}$ & $V(m / s)$ & $R e=\frac{\rho U D}{\mu}$ & $G r=\frac{\rho^{2} g \cos \theta \beta\left(T_{\text {out }}-T_{\text {in }}\right) D^{3}}{\mu^{2}} \times 10^{5}$ & $R a=G r \cdot P r * 10^{5}$ & $R i=\frac{G r}{R e^{2}}$ \\
\hline 293.15 & 6.9909 & \multirow{4}{*}{0.06377} & 634.6482 & 0.6057 & 4.2347 & 0.1503 \\
\hline 303.15 & 4.3276 & & 968.9524 & 1.3709 & 5.9327 & 0.1460 \\
\hline 313.15 & 3.5536 & & 1151.859 & 1.8882 & 6.7102 & 0.1423 \\
\hline 323.15 & 2.9833 & & 1344.023 & 2.5023 & 7.4653 & 0.1385 \\
\hline
\end{tabular}




\section{GOVERNING EQUATIONS, BOUNDARY CONDITIONS AND SOLVER SETTINGS}

The conservation laws of mass, momentum and energy in steady-state conditions are presented below:

$$
\begin{array}{cc}
\text { Continuity } & \nabla\left(\rho_{w} U_{w}\right)=0 \\
\text { Equation } & \\
\text { Momentum } & \nabla \cdot\left(\rho_{w} U_{w} U_{w}\right)=-\nabla \mathrm{P}+\nabla \tau+\rho_{w} g \\
\text { Equation } & \\
\text { Energy } & \nabla \cdot\left(\rho_{w} U_{w} C_{p_{w}} T\right)=\nabla \cdot\left(k_{w} \nabla T\right) \\
\text { Equation } &
\end{array}
$$

In the above equations, $\mathrm{P}, \tau, \mathrm{k}$ and $\mathrm{C}_{\mathrm{p}}$ represent pressure $\left(\mathrm{N} / \mathrm{m}^{2}\right)$, tension $\left(\mathrm{N} / \mathrm{m}^{2}\right)$, thermal conductivity $(\mathrm{W} / \mathrm{mK})$ and specific heat $(\mathrm{J} / \mathrm{kgK})$, respectively. Also, subscript $\mathrm{w}$ is used for water.

The pressure-based solver is activated in present model. Pressure is coupled to velocity by the SIMPLE scheme. The interpolation scheme for the convection and diffusion is the second order upwind. The solution is converged when the residual values of velocity, continuity and energy reach to $10 \mathrm{e}-4,10 \mathrm{e}-3$, and $10 \mathrm{e}-6$, respectively.

The 'velocity inlet' and 'pressure outlet' boundary conditions are applied at the inlet and outlet of tube, respectively. The no-slip wall and impermeable boundary conditions have been used over the walls. The absorbed solar radiation on the absorber plate is computed by Eq. (1). In fact, the equivalent heat flux is utilized as a wall boundary conditions of the plate.

$$
\mathrm{q}_{\mathrm{abs}}=\mathrm{G}_{\mathrm{t}} \tau_{\mathrm{g}} \alpha(1-\eta)
$$

where: $\mathrm{q}$ - heat flux on the plate $\left(\mathrm{W} / \mathrm{m}^{2}\right)$,

$\mathrm{G}$ - solar radiation intensity $\left(\mathrm{W} / \mathrm{m}^{2}\right)$,

$\tau$ - transmitivity,

$\alpha$ - absorbtance,

$\eta$ - efficiency.

Subscripts abs, $t, g$ are used instead of absorbed, total and glass cover.

The thermal and electrical efficiencies of the $\mathrm{PV} / \mathrm{T}$ system are obtained as followings:

$$
\begin{gathered}
\eta_{\text {thermal }}=\frac{\dot{m}_{w} C p_{w}\left(T_{\text {out }}-T_{\text {in }}\right)}{G_{t} \cdot A_{P}} \\
P=\frac{A_{P V}}{A_{P}} \\
\eta_{\mathrm{pV}}=\eta_{\text {ref }}\left[1-\beta\left(\mathrm{T}_{\text {cell }}-\mathrm{T}_{\text {ref }}\right)\right] \\
\eta_{\text {electrical }}=P \cdot \eta_{\mathrm{pV}}
\end{gathered}
$$

where: $\dot{\mathrm{m}}$ - mass flow rate $(\mathrm{kg} / \mathrm{s})$,

$\mathrm{A}$ - area $\left(\mathrm{m}^{2}\right)$,
$\mathrm{P}$ - packing factor.

Subscripts P, PV and cell are displayed for plate, photovoltaic and solar cell.

\section{MESH GENERATION AND GRID INDEPENDENCY TEST}

A mesh is a discretization of a domain existing in one, two or three dimensions. When the geometry is meshed, then the conservation laws can be applied in all elements created. After geometry drawing, grid generation is the second process involved in computing numerical solutions. The result of the solution depends upon the quality of grid. The absorber plate and fluid body of domain were meshed with the sweep and Patch-conforming mesh method, respectively. In order to make a boundary layer for fluid body, layers close to tube walls are inflated.

A grid study is carried out to consider the precision of the obtained results. The findings of four different grids with 882722, 921507, 1075904 and 1449128 element numbers are evaluated. The maximum water outlet velocity, the water outlet temperature and the average heat transfer coefficient are examined. It is observed that further refinement on the grid with 882722 does not have a remarkable effect on the solutions, and just imposes heavier computational cost on project. The percentage of parameter change due to mesh refinement even could not reach $3 \%$. Thus, the last grid with the fewest number of elements (882722) is selected as an optimized computational domain.

\section{VALIDATION OF SIMULATION MODEL}

The represented simulation model of $\mathrm{PV} / \mathrm{T}$ system is verified by comparing the obtained results with experimental findings [3]. Thermal efficiency is plotted versus $\left(T_{\text {inlet }}-T_{\text {ambient }}\right) / \mathrm{G}$ based on following equation:

$\eta_{\text {thermal }}=F_{R}\left[(\tau \alpha)_{\theta}\left(1-\eta_{\text {electrical }}\right)-U_{L}\left(\frac{T_{\text {in }}-T_{a m b}}{G_{t}}\right)\right](6)$

where: $F_{R}$ and $(\tau \alpha)$ are flow rate factor and Transmitivity-Absorptivity product, respectively. Also $a m b$ subscript is used to show ambient conditions.

The solar incident radiation, tilt angle of setup and water mass flow rate are set out to experi- 
mental data of $800 \mathrm{~W} / \mathrm{m}^{2}, 20^{\circ}$ and $0.044 \mathrm{~kg} / \mathrm{s}$, respectively. In various inlet temperatures, outlet parameters are monitored in numerical model. The obtained results are shown in Figure 2.

A similar trend is observed in data gathered from both simulation and experimental data. In order to evaluate the accuracy of numerical results and measure the difference between predicted and observed values, statistical formulations of RMSE and MAE are calculated in both for mentioned validations. RMSE and MAE are determined by the following equations:

$$
\begin{aligned}
\text { RMSE } & =\sqrt{\frac{1}{n}\left(\sum_{i=1}^{n}\left(e_{i}-m_{i}\right)^{2}\right)} \\
M A E & =\frac{1}{n} \sum_{i=1}^{n}\left|e_{i}-m_{i}\right|
\end{aligned}
$$

RMSE and MAE are Root mean square error and Mean absolute error, respectively. In which, e is Theoretical value, $\mathrm{m}$ is Experimental value and $\mathrm{n}$ is Number of the values.

In Figure 2, RMSE and MAE are computed $9.9 \%$ and $9.8 \%$, respectively. Therefore, it is deduced that there is a good agreement between experimental and simulation results.

\section{RESULTS AND DISCUSSION}

\section{Absorbed Solar Radiation Variations}

Absorbed solar radiation is the most important factor in the heating of the fluid passing the tubes.

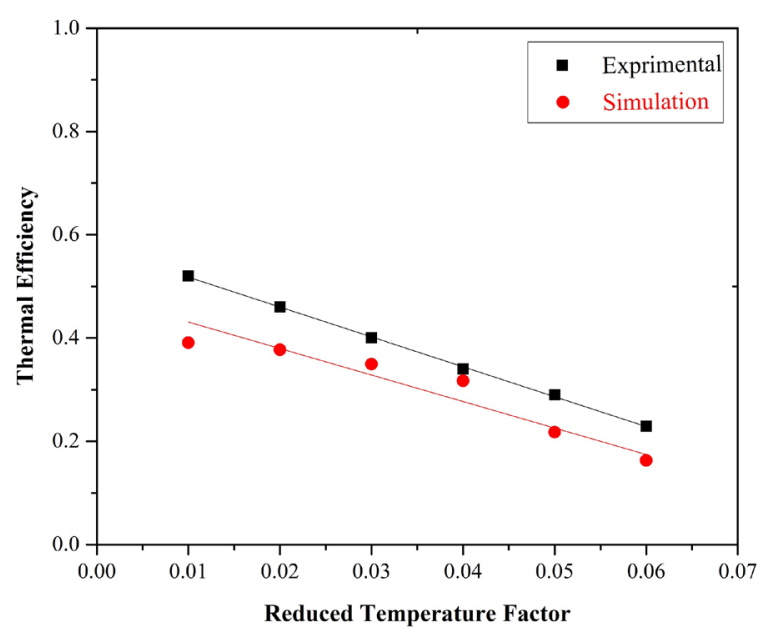

Fig. 2. Validation of PV/T model via experimental results [3]
When the solar radiation entered the photovoltaic, a certain percentage of arrived energy converts to electricity. The amount of electricity production is proportional to efficiency of PV panel. The remaining part of radiation transmits the PV panel and reaches to absorber sheet and tube. In this way, energy is transferred to fluid. This procedure leads to sheet and tube cooling and consequently fluid heating. In this investigation, the absorbed radiation is varied from $200 \mathrm{~W} / \mathrm{m}^{2}$ to $800 \mathrm{~W} / \mathrm{m}^{2}$, in constant inlet water velocity of $0.06377 \mathrm{~m} / \mathrm{s}$ and inlet water temperature of $303.15 \mathrm{~K}$.

In Figure 3, the variations of the outlet fluid temperature and absorber plate temperature versus absorbed solar radiation are displayed. As the absorbed solar radiation increases, the outlet fluid temperature grows. It is obvious that the greater absorbed solar radiation would lead to higher absorber plate temperature.

The variation of the average heat transfer coefficient versus absorbed solar radiation is illustrated in Figure 4. Heat transfer coefficient is mainly influenced by heat transfer properties. In fact, it is not dependent to environmental factors such as absorbed solar radiation. Therefore, increasing the absorbed solar radiation does not have a significant effect on the heat transfer performance of the PV/T system.

According to Eq. (2), Thermal energy efficiency is mostly dependent on outlet temperature and absorbed radiation on the plate. Figure 5 indicates the variation of efficiencies versus the absorbed solar radiation. At low absorbed solar radiation, thermal efficiency increases. While in medium and high absorbed solar radiations, thermal effi-

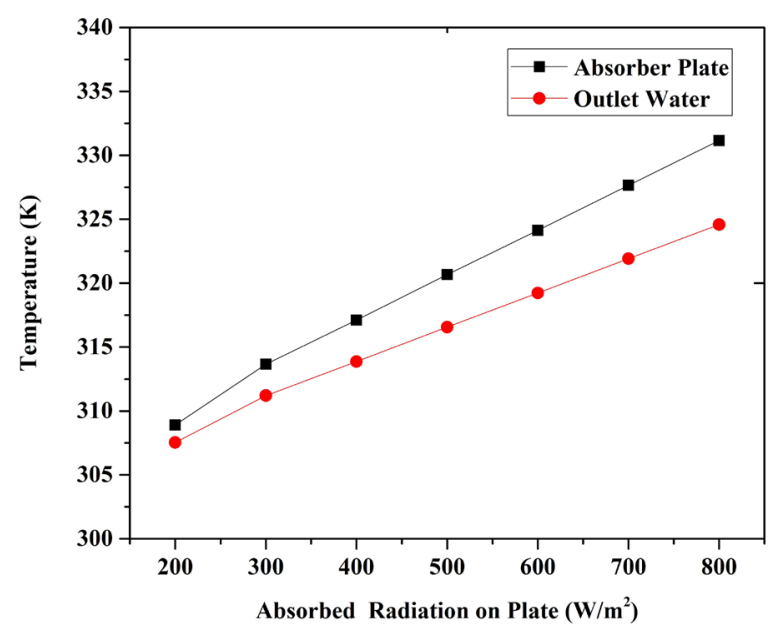

Fig. 3. Variation of the outlet fluid temperature and absorber plate temperature versus absorbed solar radiation 


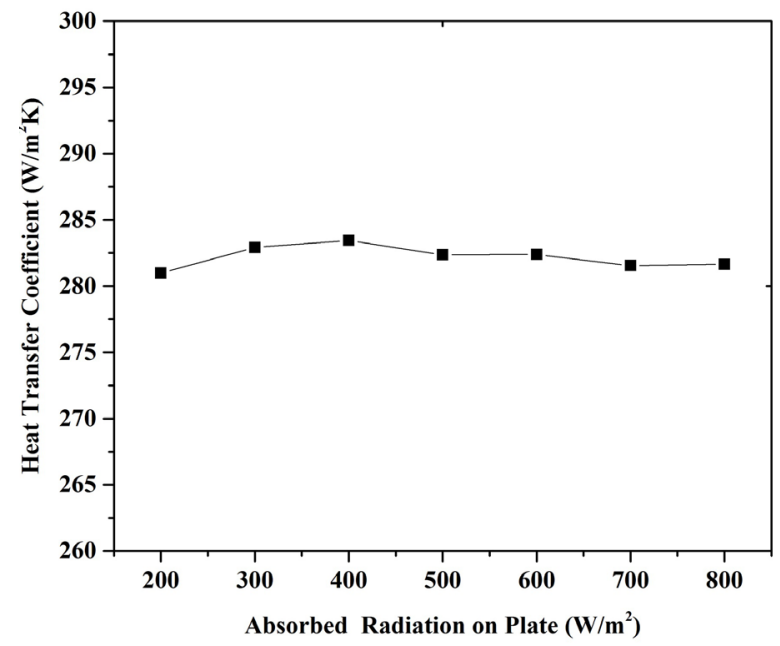

Fig. 4. Variation of the heat transfer coefficient versus absorbed solar radiation

ciency remains fixed approximately. The reason may be due to simultaneous increase of absorbed solar radiation and outlet temperature. In fact, outlet temperature increases with increasing the absorbed solar radiation. Consequently, the thermal efficiency remains approximately fixed. The electrical efficiency of the PV/T panel decreases as the cell temperature increases. This fact is proved by Eq. (4).

Considering variation of thermal efficiency versus reduced temperature factor is a suitable key for determination of thermal characteristics of $\mathrm{PV} / \mathrm{T}$ system, according to Eq. (6). Thermal efficiency of $\mathrm{PV} / \mathrm{T}$ system is plotted against reduced temperature factor or $\left(T_{i n}-T_{a m b}\right) / \mathrm{G}_{\mathrm{t}}$ in Fig. 6. As it can be seen in Fig. 6, the maximum thermal efficiency reaches up to around $80 \%$.

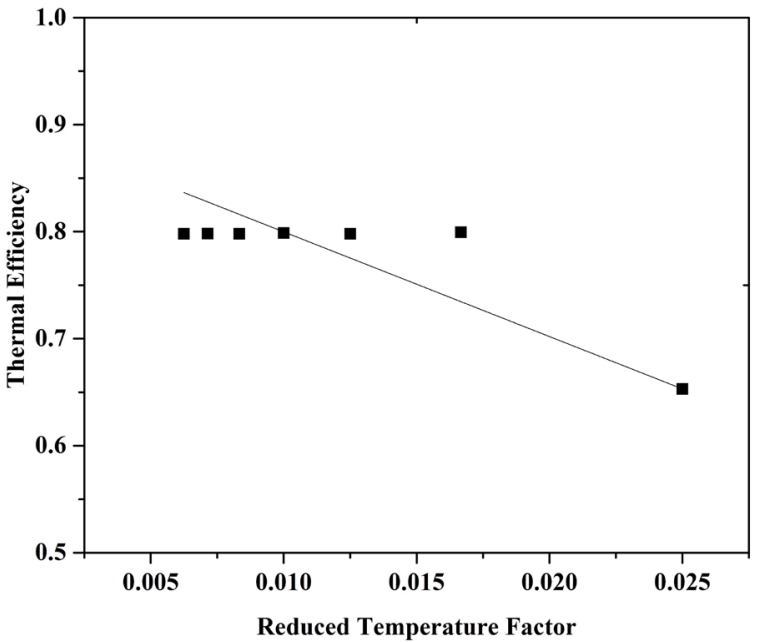

Fig. 6. Variation thermal efficiency against reduced temperature factor

\section{Inlet Water Temperature Variations}

Inlet water temperature can influence water heating and sheet and tube cooling process. In many references [10], inlet fluid temperature rise is leading to probable reduction of thermal efficiency (or remaining fixed) and almost definite decrease in electrical and overall efficiency. Absorbed solar radiation has a significant effect on selection of an optimized value for inlet water temperature. At high absorbed solar radiation amounts, the cooling effect of passing water with relatively high inlet temperature, is almost remarkable as well. At low absorbed solar radiation values, high inlet water temperatures lead to heat the PV cells instantaneously. While low inlet water temperatures have a cooling effect at all solar radiation levels. There-

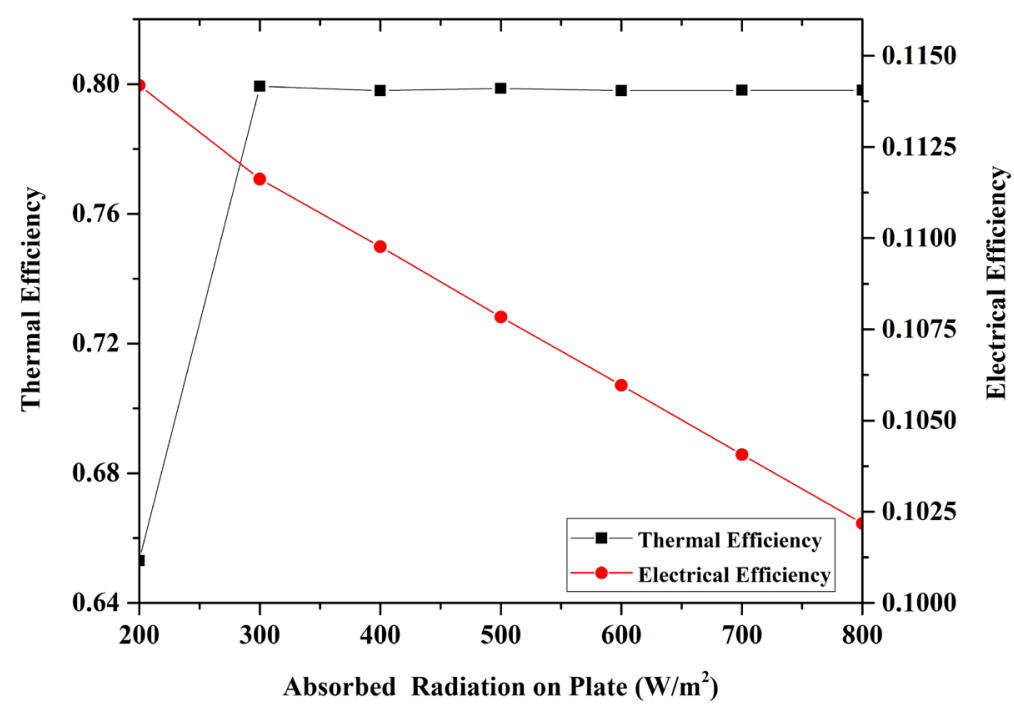

Fig. 5. Variation of efficiencies versus the absorbed solar radiation 


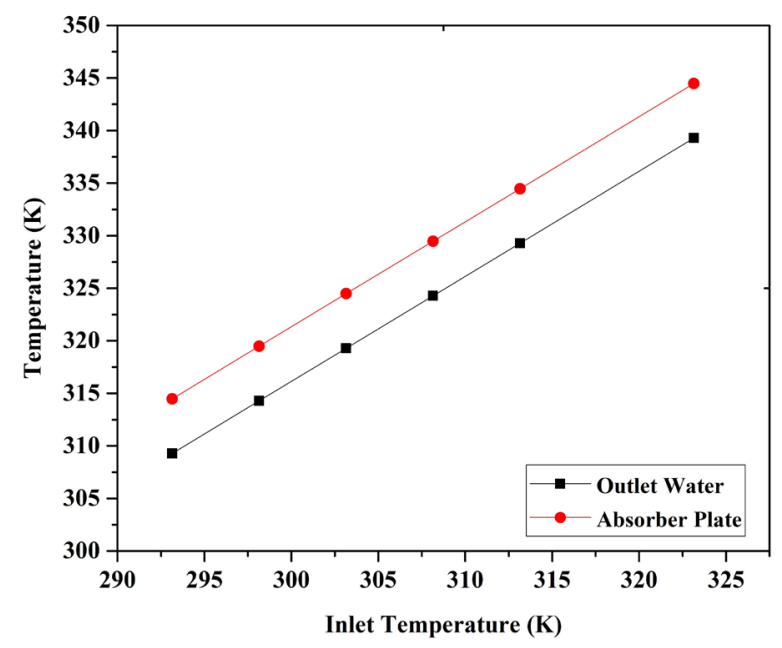

Fig. 7. Variation of the outlet fluid temperature and absorber plate temperature versus inlet temperature

fore, the lower inlet temperature provides a more appropriate conditions for $\mathrm{PV} / \mathrm{T}$ system. It must be noted that raising inlet water temperature and consequently operation temperature of system, heat transfer characteristics such as convection heat transfer coefficient varies.

In the present work, the inlet water temperature is varied from $20{ }^{\circ} \mathrm{C}$ to $50{ }^{\circ} \mathrm{C}$ in constant absorbed solar radiation of $600 \mathrm{~W} / \mathrm{m}^{2}$ and tilt angle of $35^{\circ}$. The variations of the outlet water temperature and absorber plate temperature versus the inlet water temperature are indicated in Figure 7. As can be observed in Figure 7, temperature increase at tube outlet is mainly dependent to inlet water temperature. So it is realized that the higher inlet water temperature causes in greater outlet temperature. Also greater inlet water temperature would lead to higher absorber plate temperature.

Figure 8 displays the variation of the efficiencies versus the inlet water temperature. Thermal efficiency remains approximately fixed with respect to increasing the inlet water temperature. Increasing the inlet water temperature increases the absorber plate temperature. This would cause in PV panel temperature rise. Consequently, electrical efficiency fall is expected in such circumstances.

In low inlet water temperature, heat transfer coefficient has not been varied significantly. Whereas in higher inlet water temperature, operational temperature of $\mathrm{PV} / \mathrm{T}$ system increases. This results in heat transfer coefficient improvement.

In the current investigation, the temperature distribution is considered in form of contour. The temperature contour for absorber plate and outlet water is illustrated in Figures 9 and 10. The temperature contour is obtained with the tilt angle of $35^{\circ}$, inlet water velocity of 0.06377 $\mathrm{m} / \mathrm{s}$, inlet water temperature of $303 \mathrm{~K}$, and solar radiation of $800 \mathrm{~W} / \mathrm{m}^{2}$. As can be seen in the sketch of the model in Figure 1, the tube is placed at the middle of the absorber plate. It is observed that temperature increases in the paths of both tube center to the wall, and inlet to the outlet. The temperature contour of the absorber plate shows excess temperature at the edge of the absorber plate. This is due to the fact that this part of absorber plate does not contain the tube cooling effects. Thus, there is no effective heat sink at these locations and this results in rising the temperature.

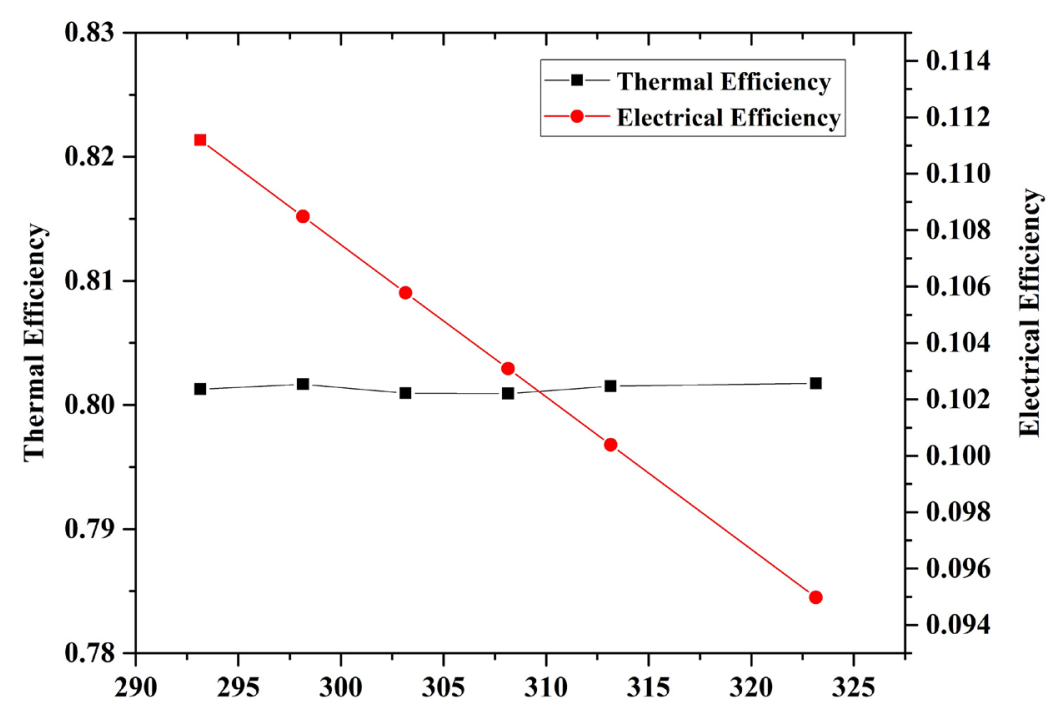

Fig. 8. Variation of efficiencies versus the inlet water temperature 


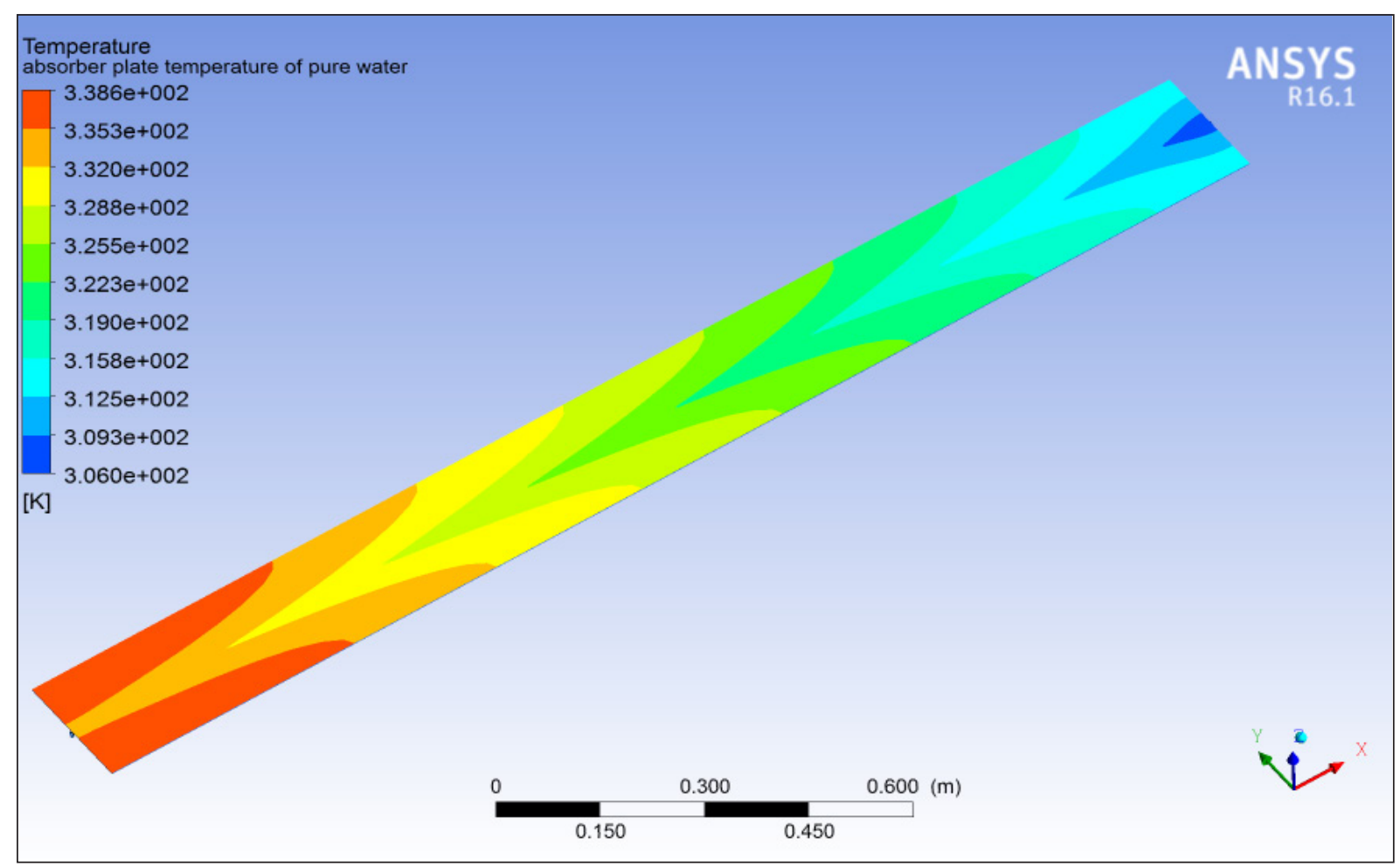

Fig. 9. Temperature distribution of absorber plate

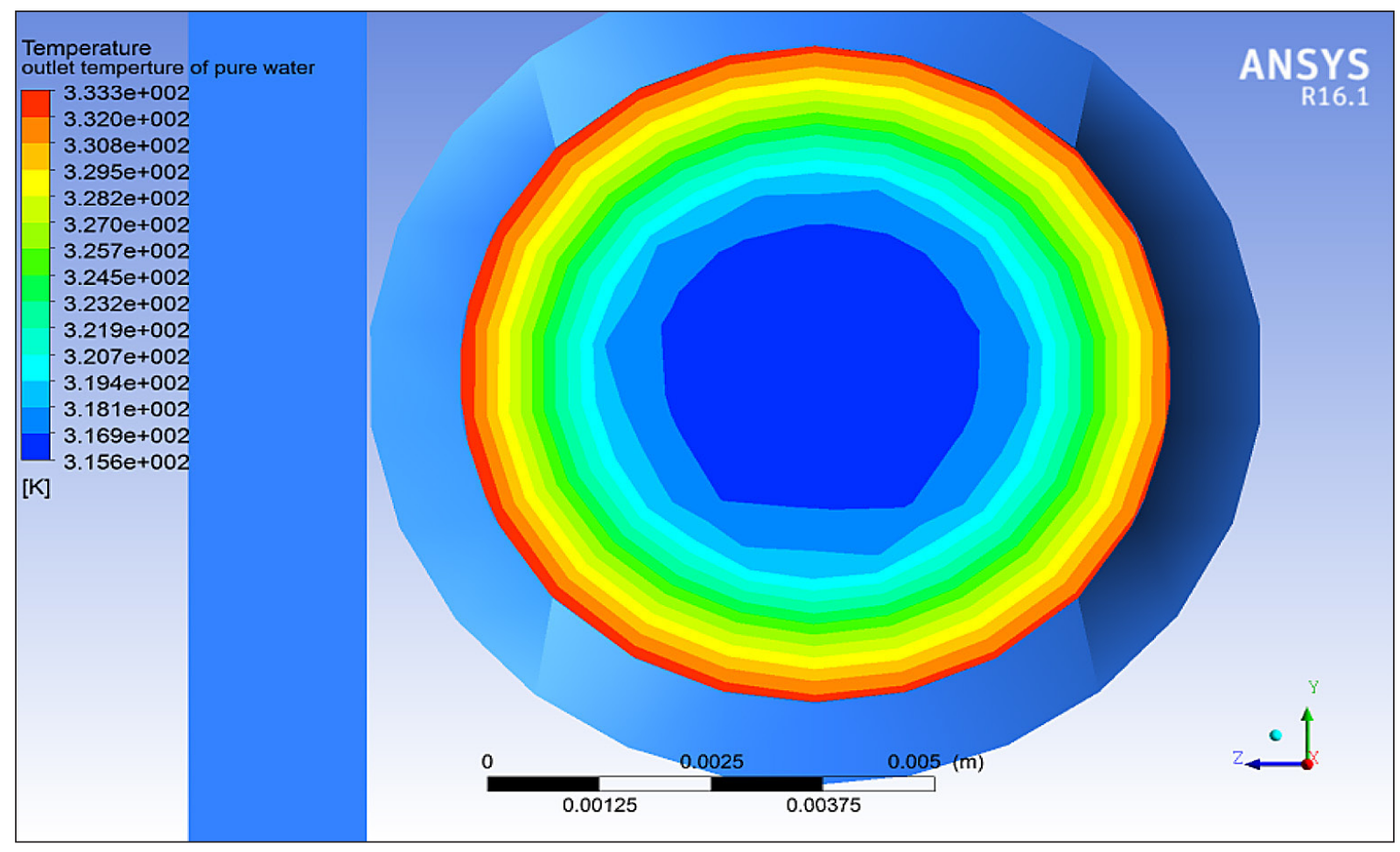

Fig. 10. Temperature distribution of outlet water

\section{CONCLUSIONS}

The current study aims to consider the performance of a liquid-based PV/T system by a numerical investigation. An attempt is being made in this paper to numerically analyze the liquid cooled PV/T system using the CFD method. In the present work, a 3D model of a simplified $\mathrm{PV} / \mathrm{T}$ system including water tube and absorber plate is simulated to provide a comprehensive 
thermal analysis. For obtaining the numerical results, the conjugate heat transfer analysis methodology was applied. The effects of varying the inlet water temperature and absorbed solar radiation are considered. The temperature distribution through the absorber plate and the outlet water temperature are evaluated in form of temperature contours. The measured data attained by the CFD simulations were compared with experimental results in the literature. The numerical simulation results are in good agreement with the experimental measurements in the literature.

\section{REFERENCES}

1. Aragonés-Beltrán P., Chaparro-González F., Pastor-Ferrando J.-P. and Pla-Rubio A. An AHP (Analytic Hierarchy Process)/ANP (Analytic Network Process)-based multi-criteria decision approach for the selection of solar-thermal power plant investment projects. Energy, 66, 2014, 222-238.

2. Aste N., Leonforte F. and Del Pero C. Design, modeling and performance monitoring of a photovoltaic-thermal (PVT) water collector. Solar Energy, 112, 2015, 85-99.

3. Bhattarai S., Oh J.-H., Euh S.-H., Krishna Kafle G. and Hyun Kim D. Simulation and model validation of sheet and tube type photovoltaic thermal solar system and conventional solar collecting system in transient states. Solar Energy Materials and Solar Cells, 103, 2012, 184-193.

4. Cerón J.F., Pérez-García J., Solano J.P., García A. and Herrero-Martín R. A coupled numerical model for tube-on-sheet flat-plate solar liquid collectors. Analysis and validation of the heat transfer mechanisms. Applied Energy, 140, 2015, 275-287.

5. Chow T.T. Performance analysis of photovoltaicthermal collector by explicit dynamic model. Solar Energy, 75(2), 2003, 143-152.

6. Chow T.T. A review on photovoltaic/thermal hybrid solar technology. Applied Energy, 87(2), 2010, 365-379.

7. Ekramian E., Etemad S.G. and Haghshenasfard M. Numerical analysis of heat transfer performance of flat plate solar collectors. Journal of Fluid Flow, Heat and Mass Transfer, 1, 2014, $38-42$.
8. Kasaeian A., Eshghi A.T. and Sameti M. A review on the applications of nanofluids in solar energy systems. Renewable and Sustainable Energy Reviews, 43, 2015, 584-598.

9. Mahian O., Kianifar A., Kalogirou S.A., Pop I. and Wongwises S. A review of the applications of nanofluids in solar energy. International Journal of Heat and Mass Transfer, 57(2), 2013, 582-594.

10. Moradi K., Ali Ebadian M. and Lin, C.-X. A review of PV/T technologies: Effects of control parameters. International Journal of Heat and Mass Transfer, 64, 2013, 483-500.

11. Perino M., Corrado V., Haurant, P., Ménézo, C., Gaillard, L. and Dupeyrat, P. Numerical Model of a Solar Domestic Hot Water System Integrating Hybrid Photovoltaic/Thermal Collectors. Energy Procedia 78, 6th International Building Physics Conference, IBPC, Torino, Italy 2015, 1991-1997.

12. Selmi M., Al-Khawaja M.J. and Marafia A. Validation of CFD simulation for flat plate solar energy collector. Renewable Energy, 33(3), 2008, 383-387.

13. Spertino F., D’Angola A., Enescu D., Di Leo P., Fracastoro G.V. and Zaffina R. Thermal-electrical model for energy estimation of a water cooled photovoltaic module. Solar Energy, 133, 2016, 119-140.

14. Tagliafico L.A., Scarpa F., Tagliafico G. and Valsuani F. An approach to energy saving assessment of solar assisted heat pumps for swimming pool water heating. Energy and Buildings, 55, 2012, 833-840.

15. Tonui J.K. and Tripanagnostopoulos Y. Aircooled PV/T solar collectors with low cost performance improvements. Solar Energy, 81(4), 2007, 498-511.

16. Tse K.-K., Chow T.-T. and Su Y. Performance evaluation and economic analysis of a full scale water-based photovoltaic/thermal (PV/T) system in an office building. Energy and Buildings, 122, 2016, 42-52.

17. Usama Siddiqui M., Arif A.F.M., Kelley L. and Dubowsky S. Three-dimensional thermal modeling of a photovoltaic module under varying conditions. Solar Energy, 86(9), 2012, 2620-2631.

18. Zondag H.A., de Vries D.W., van Helden W.G.J., van Zolingen R.J.C. and van Steenhoven A.A. The yield of different combined PV-thermal collector designs. Solar Energy, 74(3), 2003, 253-269. 